\title{
OFFICE LAYOUT AND WORKSPACE ENCLOSURE AS MEDIATORS TO WORKERS' PRIVACY AND COMMUNICATION AFFECTING PRODUCTIVITY
}

\author{
生産性に影響する就業者のプライバシーとコミュニケーションに対する媒介としての \\ オフィスレイアウト及びワークスペースの囲み \\ Gabor NAGY*, Kunio FUNAHASHI**, Takeshi SUZUKI***, \\ Michihiro KITA*** and Bin LI**** \\ ナジガボール, 舟橋國男, 鈴木 毅, 木多道宏, 李斌
}

\begin{abstract}
This study is part of a complex research on current Japanese office environments. Based on qualitative and quantitative data from group interviews and questionnaires, 'free-layout' and seating positions in 'isle-type' layout, as well as levels of workspace enclosures were defined and then cross-tabulated by the following psychophysical environmental characteristics: visual- and acoustical privacy (noise issues) and ease of communication. 'Layout differences did not have strong effects on privacy and noise issues, but affected intersectional communication. Seating positions affected workers' visual and acoustical privacy, as well as communication. Enclosure levels had the strongest mediating effects on privacy and communication. Communication and visual privacy showed significant positive correlations with different facets of productivities. Noise and lack of privacy were pointed out as most serious issues.
\end{abstract}

Keywords: office layout, seating positions, workspace enclosure, privacy, communication, productivity キーワード：オフィスレイアウト、座席位置、ワークスペースの囲み、プライバシー、コミュニケーション、生産性

\section{Research Objectives}

This study is part of a broad scale, complex research on office environments. Figure 1 shows the hypothesized holistic model that was set up to describe the relationship between physical characteristics of the workplace, workers perception, and their job and environmental satisfaction, all possibly affecting productivity.

The main purpose of this study is to investigate workers' visual and acoustical privacy, as well as ease of communication, which are suggested to be mediated by the office layout, seating positions and individual workspace enclosures. It is hypothesized that noise has an avert effect on workers' performance, while privacy and ease of communication enhances productivity. It is also hypothesized that layout and enclosure affect ease of communication; and the latter one also affects workers' visual and acoustical privacy.

This study does not deal with objectively measured physical issues; rather, it approaches from subjective questioning and self-reporting of workers, using generally categorized models. Thus, the results are solely based on users' perception of the physical and psychophysical environment.

\section{Background of the Study}

\subsection{The Physical Characteristics of Offices}

Brennan et al. (2002) " describe the work environment as a system consisting of physical (workspace, corridors for movement, etc.), social

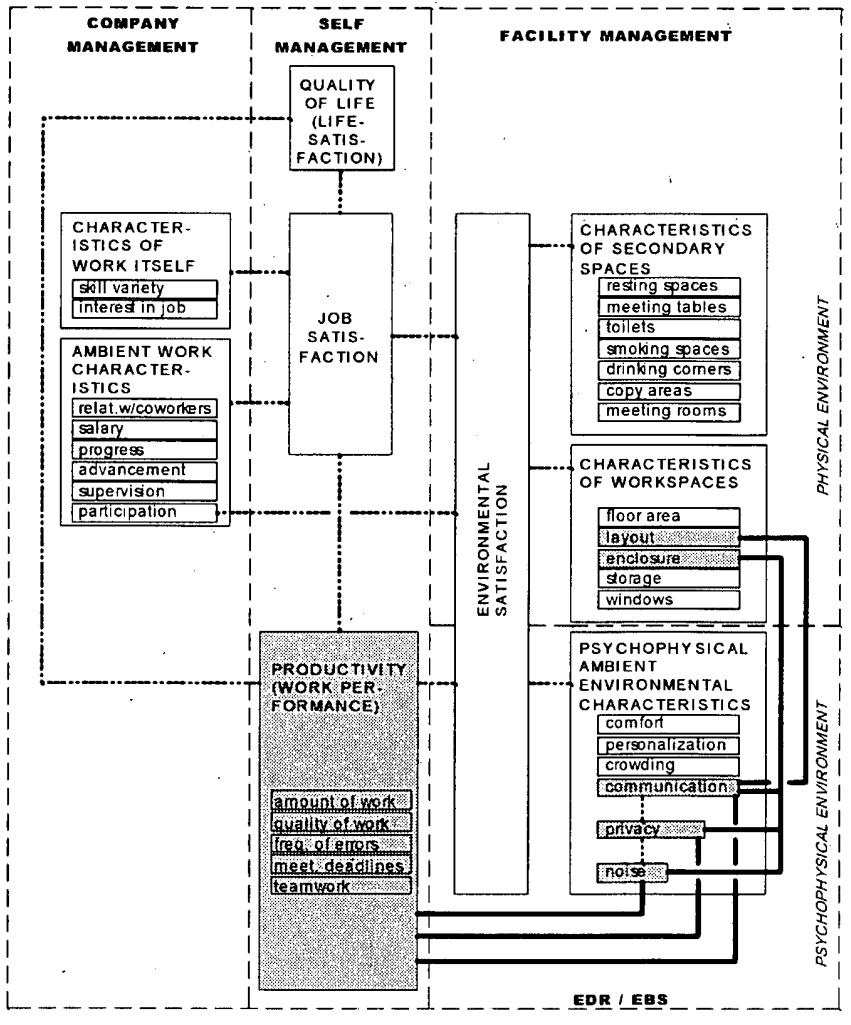

Figure 1. Research model (Shaded areas indicate limitations of discussions, and solid lines indicate hypothesized relationships in this paper)

\footnotetext{
* Osaka University., Dr. Eng.

** Prof., Emeritus, Osaka University, Dr. Eng.

*** Assoc. Prof., Dept. of Architectural Engineering, Graduate School of Engineering, Osaka University, Dr. Eng.

**** Assist. Prof., Dept. of Architectural Engineering, Graduate School of Engineering, Osaka University, Dr. Eng.
}

大阪大学 而博

大阪大学 名誉教授・而・博

大阪大学大学院工学研究科建築工学専攻 助教授・工博

大阪大学大学院工学研究科建築工学専攻 助手・工博 
(like team member relations), and psychosocial factors (communication, privacy and environmental control) ${ }^{\text {a) }}$. Physical features of the work environment contribute to the overall organizational climate of the workplace (Kupritz, 2000) ${ }^{2}$. It is also known, that workplace design can enhance or inhibit individual, group and organizational effectiveness (Brill et al., 1984) ${ }^{3)}$.

Brill et al. $(2001)^{4)}$ defines 'open office' as "a workspace ${ }^{\text {h) }}$ whose perimeter boundaries do not go to the ceiling". Open offices can vary according to their layout from the most open and simple "bull pen" in which the desks are arranged in strict rows to "landscape offices" ") that integrate "systems furniture" d) and partitions of different sides and heights.

Research on open offices and workers' behavior has showed quite mixed findings: among positive outcomes, Zahn (1991) ${ }^{5}$, Oldham et al. $(1979)^{6)}$, Ellis et al. (1980) ${ }^{7)}$, and Boyce (1974) ${ }^{8)}$ all found increased communication among coworkers, while Brookes et al. (1972) ") reported more group sociability. Zeitlin's $(1969){ }^{1(1)}$ research findings indicated overall satisfaction with the landscaped office, even though it was implied that job performance and satisfaction cannot be facilitated by the office layout.

On the other side, negative findings have been more numerous. They include decreased performance and environmental dissatisfaction among workers (Oldham et al., $1979^{6}$ ), Hedge, $1982^{11)}$, and Canter, $1972^{12)}$ ), lower levels of psychological privacy (Brookes et al., $1972^{4)}$ and Hedge, $1982^{11)}$ ), and disturbance (Canter, $1972^{\text {(2) }}$, Ellis et al., $1980^{7}$, Brookes et al., $1972^{9)}$ and Hedge, $1982^{11)}$ ). Brennan et al. (2002) "found that open office design may reduce communication since it prohibits confidential conversations, while Oldham et al. $(1979)^{\text {() }}$ and Boyce $(1974){ }^{\text {8) }}$ found open-plan offices noisy and distracting. Sundstrom $(1978)^{13)}$ found that social contact in open offices can exceed an optimum level, causing the worker to feel crowded. Rader et al. (1981) ${ }^{14)}$ suggested a non-empirical relationship between factors in the office setting initiated by the open plan, and issues of stress and low productivity.

Brill et al. (1984) ${ }^{3)}$ refers enclosure as "the nature and configuration of the physical barriers that separate a workspace from other areas in the office." Enclosure (or the opposite: openness) has been measured as a function of design characteristics, such as number of partitions surrounding the workspace, and height of partitions. Thus, open office has many variations according to the number of partitions, openness, and architectural accessibility (Oldham, $1988{ }^{15}$ ), and Oldham et al.,1983 $\left.{ }^{(6)}\right)$. Brill et al. $(1984)^{3)}$ examined workers' reactions to the height of partitions and defined three levels of enclosure: low panels, high panels and walls. They found a positive relationship between partition height and increased privacy, communication and job performance. It was also found that the number of partitions enclosing the space can mediate the effects of partition heights. Sundstrom et al. (1980) ${ }^{17)}$ reported that privacy, satisfaction with workspace and performance increase with the number of partitions. O'Neill (1994) ${ }^{1 \text { (t) }}$ also found a positive relationship between the number of partitions and enhanced reactions. Akiyama et al. $(1995)^{(1)}$ reported that work area satisfaction does not merely depend on physical factors, but also determined by workers' interactions in a group.

The Japanese equivalent of the bullpen is the 'isle-type' layout "), which is mostly used in the offices. It is believed that open layouts generally facilitate greater communication, which in turn, facilitates greater productivity (Boje, $1971^{2(1)}$; Pile, $1978^{21)}$ ): the isle-type layout with no or low partitions is believed to enhance communication by allowing constant eye contacts.

Free layout " on the other hand usually encompasses more / higher partitions, thus believed to provide private spaces with more privacy.

\subsection{Psychophysical Factors in Offices}

Workers in open offices work in physical proximity to others with some, or no physical boundaries (Brennan et al., 2002) ${ }^{1}$. These physical characteristics of the office are said to affect workers' privacy and interpersonal communication.

Privacy in the work environment generally refers to the ability to regulate the flow of information and social contact, both incoming and outgoing (Sundstrom, 1986) ${ }^{22}$. Privacy, a common characteristic of self-protection, can be real or perceived and can be achieved through physical or social innovation (Kupritz, 1998) ${ }^{23}$. There are different types of privacies, such as 'speech or conversational privacy' '), 'acoustical privacy' h), and 'visual privacy' i). The visual and acoustical isolation supplied by the physical design of an environment typically is called 'architectural privacy' (Kupritz, 2003) ${ }^{24)}$. Research shows that employees associate psychological privacy with architectural privacy (Sundstrom et al. 1980) ${ }^{17}$. Thus, perceived privacy is correlated with actual physical enclosure (Sundstrom et al., 1982) ${ }^{25)}$. Kupritz (1998) ${ }^{23)}$ found that visual and acoustical distractions, consequences of lack of privacy can decrease workers' productivity and increase errors. Sundstrom et al. (1980) ${ }^{17)}$ also found a positive correlation between privacy and performance. In Brennan et al.'s (2002) ') survey of open offices the primary complaints by workers were lack of privacy and confidentiality, and increased noise. Akiyama et al. $(1996)^{26)}$ found that privacy and communication were not merely determined by the office's physical properties, but also depended on the activities performed there.

Noise, refers to unwanted or irrelevant sound (Landy et al., 1980) ${ }^{27)}$. Office workers hear sounds from many sources, like office machines, phones ringing, people talking, etc. Such sounds become noise to those who prefer not to hear them (Brill et al., 1984) ${ }^{3}$; thus, people talking may be important source of information to some, but considered noise by others. In the 1978 Steelcase survey (Harris, et al., 1978) ${ }^{28)}$, office workers identified "the ability to concentrate without noise and other distractions", as the most important of 16 features of the office environment. In Brill et al's (2001) ${ }^{4)}$ survey, the "ability to do distraction-free solo work" was also No.1. among 10 factors. Noise is a potentially serious problem for office workers, because its adverse effects of job related stress (Kahn et al., 1992) ${ }^{24)}$. Boyce $(1974)^{8)}$ found that more than half of the workers in open plan offices were disturbed by noise, and $55 \%$ of the noise came from people talking. Nemecek et al. (1973) ${ }^{3(1)}$ also reported that more than a third of workers complained of noise, particularly conversations among co-workers. Miura et al. $(2001)^{31)}$ found positive correlations between indoor noise and area of space. However, Sundstrom et al. (1994) ${ }^{32)}$ did not find any relationship between noise and performance. Despite noise has been shown to affect physiological processes, Takahashi et al. $(2001){ }^{33)}$ pointed out that exposure to mild noise in office environments had not been well studied or documented.

While most of the 'noise' comes from people talking, adequate communication is a must to accomplish the goals of an organization. It is one of the major factors related to interpersonal relationships 
influenced.by the furniture and office layout (Ha et al., 2002) ${ }^{34)}$. The transfer of information can occur through many different channels, such as face-to-face, telephone, e-mail, etc. According to Brill et al. (1984) ${ }^{3)}$, many of today's experiments to increase productivity use enhanced communication as their method (Quality Circles) or as they product (electronic mail). In BOSTI's ${ }^{\text {j) }}$ newest survey (Brill et al., 2001) ${ }^{4)}$, it was reported that $87 \%$ of the workers learned the most through informal interactions (as opposed to formal meetings), however, 58\% of workers in open offices did not learn anything from unwittingly overhearing others' conversations.

\section{Methods of the Study}

\subsection{Group Interviews}

A comprehensive question sheet addressed questions about individual workspaces, communication, privacy, and environmental satisfaction, etc. 19 group interviews of office workers were carried out at 17 different large Japanese companies with 42 workers ( 33 men and 9 women). Pictures were taken (a total of 1077) and floor plans were collected of almost all the offices ${ }^{k}$. Part of the findings of the intervièws are discussed in this study.

\subsection{Questionnaire Survey}

Our questionnaire consisted of 74 questions which covered the overall research model in Figure 1. Table 1 shows the overall structure of the questionnaire and the limitations of this paper.

\begin{tabular}{|c|c|c|}
\hline CATEGORIES & SUBCATEGORIES & NO. OF Q UESTIONS * \\
\hline \multirow{3}{*}{ Denoge r aphical char acteristics } & Personal & $3(2)$ \\
\hline & Dob description & $-4 \mathrm{l})$ \\
\hline & Others & 5 \\
\hline \multicolumn{2}{|l|}{ Quality of life } & $T$ \\
\hline \multicolumn{2}{|l|}{ Characteristics of work itself } & 2 \\
\hline \multicolumn{2}{|l|}{ Ambient work characteristics } & 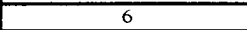 \\
\hline \multicolumn{2}{|l|}{ Job satisfaction } & $T$ \\
\hline \multirow{3}{*}{$\begin{array}{l}\text { Characteristics of physical } \\
\text { worlispace. }\end{array}$} & Liyout & $2(1)$ \\
\hline & Enclosure & $\mathbf{S}^{5}$ \\
\hline & Others & 5 \\
\hline \multirow{4}{*}{$\begin{array}{l}\text { Psychophysical ambient- } \\
\text { eavironmental char acteristics }\end{array}$} & Frivacy & (S) \\
\hline & Conmaunication & $7(6)$ \\
\hline & Foise & 5 \\
\hline & Others & 4 \\
\hline \multicolumn{2}{|c|}{ Sitis action with work emvironinent } & 271 \\
\hline \multicolumn{2}{|l|}{ Characteristics of secondary spaces } & 6 \\
\hline \multirow{2}{*}{ Productivity / workper formance } & Overall productivity & 2 \\
\hline & Facets of productivity & 64) \\
\hline \multicolumn{2}{|c|}{ free writing } & 1 \\
\hline \multicolumn{2}{|l|}{ Totul number of questions: } & $74(.33)$ \\
\hline
\end{tabular}

Table 1. Question categories in the questionnaire (Shaded areas indicate discussed issues in this article. ${ }^{*}$ No. of questions analyzed in this paper are shown in ()).

\begin{tabular}{|c|c|c|}
\hline $\begin{array}{l}\text { Profile of } \\
\text { companies. }\end{array}$ & $\begin{array}{l}\text { Norof collected } \\
\text { quest tonnaires }\end{array}$ & ror of \\
\hline construction & 506 & 49.3 \\
\hline industrial & 195 & 19.0 \\
\hline governmental & 130 & 12.7 \\
\hline service & 82 & .8 .0 \\
\hline product m anufact. & 22 & 2.1 \\
\hline trading & 23 & 2.2 \\
\hline gas provider. & 21 & 2.0 \\
\hline advertising & 14 & 1.4 \\
\hline software & 10 & 1.0 \\
\hline telecommunication & 10 & 1.0 \\
\hline banking & 5 & 0.5 \\
\hline other & 8 & 0.8 \\
\hline Total: & 11126 & 1001.0 \\
\hline
\end{tabular}

\begin{tabular}{|c|c|c|}
\hline $\begin{array}{l}\text { Gender of } \\
\text { respondents }\end{array}$ & No. & 18 \\
\hline Male & 741 & 72.2 \\
\hline Female & 285 & 27.8 \\
\hline Age of respondents & No: & $\%$ \\
\hline under 25 & 47 & 4.6 \\
\hline $25-34$ y rs old & 436 & 42.5 \\
\hline $35-44$ y rs old & 281 & 27.4 \\
\hline $45-54$ y rs old & 165 & 16.1 \\
\hline $55-64$ y rs old & 83 & 8.1 \\
\hline no answer & 14 & 1.3 \\
\hline $\begin{array}{l}\text { Eefight or Ture at } \\
\text { present wor uspace }\end{array}$ & N & $\%$ \\
\hline$<1$ year & 331 & 32.3 \\
\hline 1.5 y ears & 596 & 58.1 \\
\hline $6-10$ years & 64 & 6.2 \\
\hline$>10$ years & 23 & 2.2 \\
\hline no answer & 12 & 1.2 \\
\hline
\end{tabular}

Table 2. Demographical characteristics of respondents and profile of their companies in the questionnaire
The pre-tested questionnaires were distributed to several companies with open office layouts (42 offices at various locations in major cities in Japan). With a return rate of $84.3 \%, 1039$ workers answered the questionnaire. 13 questionnaires were discarded because of insufficient information. The remaining $98.8 \%, 1026$ questionnaires served as the main database (Table 2).

\section{Discussion}

\subsection{Qualitative Findings from Group Interviews}

The group interviews revealed mixed findings regarding workers' perceptions about their work environment. During the interviews, we noted that usually upper management decided the layout of the office, the isle-type layout being the far most popular. The seating order in each isle was decided by the section chiefs. Below, we summarize the findings of the group interviews, and from its qualitative nature, instead of percentage values we discuss trends and worker opinions based on the majority (generally about $2 / 3^{\text {rd }}$ ) of workers.

Generally, it was believed by many, that in an open office with no partitions, communication was easier. On the other hand, there was a strong need for at least a minimum privacy. Managers said they liked to see their subordinates, however workers' opinion about 'being constantly watched' were usually the opposite: most of them felt it as a strong lack of privacy. Group communication was found to be very important, and workers defined the necessity, of having partitions at least between the isles to increase group privacy. Some workers thought that the open layout did not necessarily enhance communication, because a required level of privacy could not be achieved.

Regarding individual partitions, most workers felt their necessity for an optimum level of visual privacy. Low partitions seemed to be able to provide some level of privacy, while keeping the office look more spacious. Those who felt necessary to have enclosure considered medium-height partitions to be the best: here they could achieve a satisfactory level of privacy while sitting, but the space could be overseen when standing. Some workers felt that if they were surrounded by partitions, the space in between would feel more like their territory, however the overall office would feel more crowded.

In most cases, different sections and departments were working in the same open office, which was a source of much noise. Most workers considered their office noisy, and most of the cases the source of noise were unwanted, overheard conversations or people talking on phones. Noise was described by many as stressful. In a seemingly easy-tocommunicate open layout, it was interesting to note that some workers considered the lack of communication stressful.

Some workers defined the ideal layout where everyone had private workspaces to concentrate, with common places in between the isles for information exchange between team members.

\subsection{Quantitative Findings from the Questionnaire Survey 4.2.1. Layout, Seating Positions and Levels of Enclosures}

All the questionnaires were taken in open offices (see Section 2.1 for definition). In this study, we discuss 2 kinds of open offices: isletype layout ${ }^{\text {c) }}$ and free layout. ') While at the 'other' category workers drew or explained their layout (not discussed in this paper), at the 'isletype' category workers checked their seating positions among 3 'zones' (Table 3): end of the row (END), middle of the row (MID) and head of 


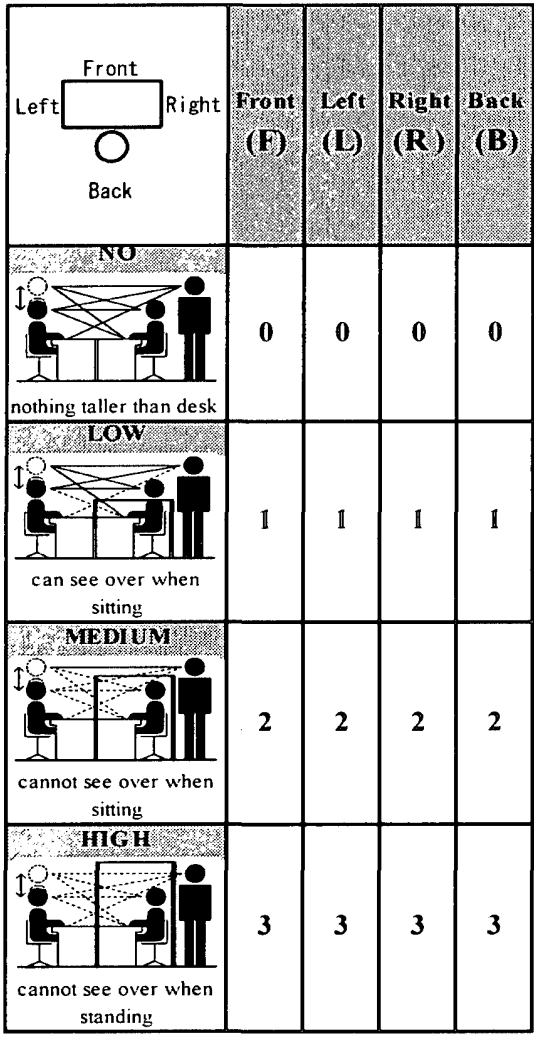

Table 4. Categories of partitions (heights and sides)

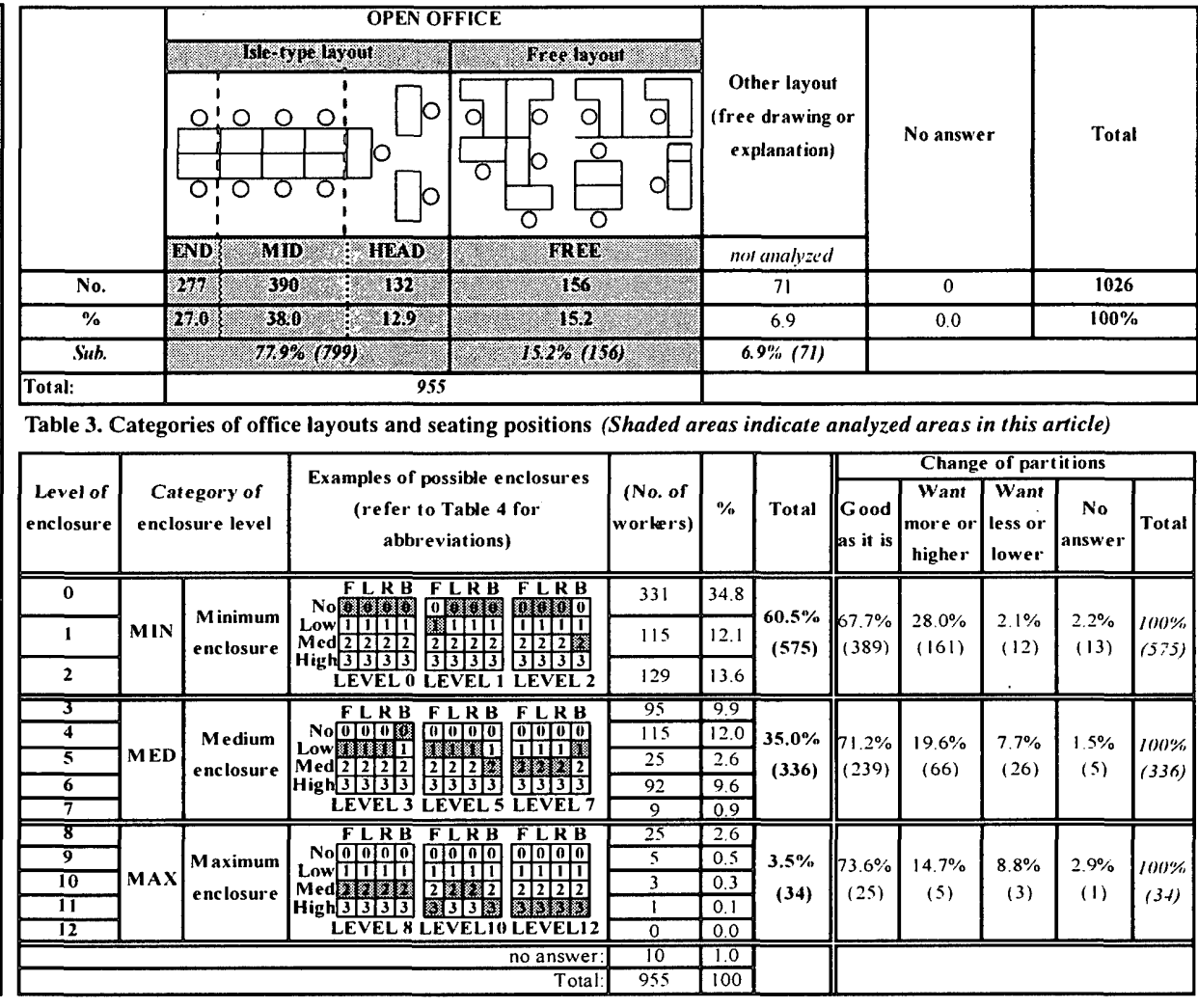

Table 5. Categories of enclosure levels and users' wishes to change their partitions (\% values show distributions within one enclosure (evel) the row (HEAD).

Our sample consisted of $77.9 \%$ workers working in the isle-type layout. $15.2 \%$ worked in free layout, and the remaining $6.9 \%$ ('other') consisted of different minor layout types ". In this study we analyze and compare data from the first two major layout types, thus leaving 955 workers in the main database (Table 3).

Enclosure was defined by the combination of different heights and numbers of partitions around individual workspaces. Partition heights were subjectively measured based on individual perceptions. Four categories of partition heights were set up (Table 4.) based on workers' perceived visual privacy and were coded from 0 to 3 . These were combined with the possible 4 sides, and 13 levels of enclosure were defined (Table 5). Based on the findings from the interviews and BOSTI's survey (Brill, et al. $1984{ }^{3}$ ), 3 categories of enclosure levels were set up for further analyses. Most workers in our sample (60.5\%) worked in minimum enclosure workspaces. $34.8 \%$ of all workers had no partitions at all and nobody from the sample had Level 12 enclosure. Maximum enclosure was very rare also (3.5\%). Since 10 people did not answer here, only the remaining 945 sample were further analyzed.

To the question: 'How would you like your partitions to be?', answers were cross-tabulated by the 3 enclosure categories (see rightside of Table 5). Almost one-third (28.0\%) of workers with minimum enclosure workspaces wanted more or higher partitions, and only less than $10 \%$ of workers with medium or maximum enclosure wanted less or lower partitions. However, more than two-third of workers in all levels of enclosures answered that they did not need any change.

The 3 seating positions -in the isle-layout, together with the free layout and the 3 enclosure levels define 12 main variations of individual workspaces (from END-MIN to FREE-MAX, see upper part of Table 6).
Workers' perceptions of their psychophysical environment (perceived visual and acoustical privacy, and ease of communication) were investigated by cross-tabulations within these 12 categories. Most workers $(28.5 \%$ ) fell into the MID-MIN category; that is, they sat in the middle of the row in the isle-layout, with minimum enclosure around their workspaces. None of the workers had maximum enclosure in the MID position, and due to insufficient number of sample in the HEADMAX category, data was not analyzed here. Most workers in the free layout had medium enclosure levels.

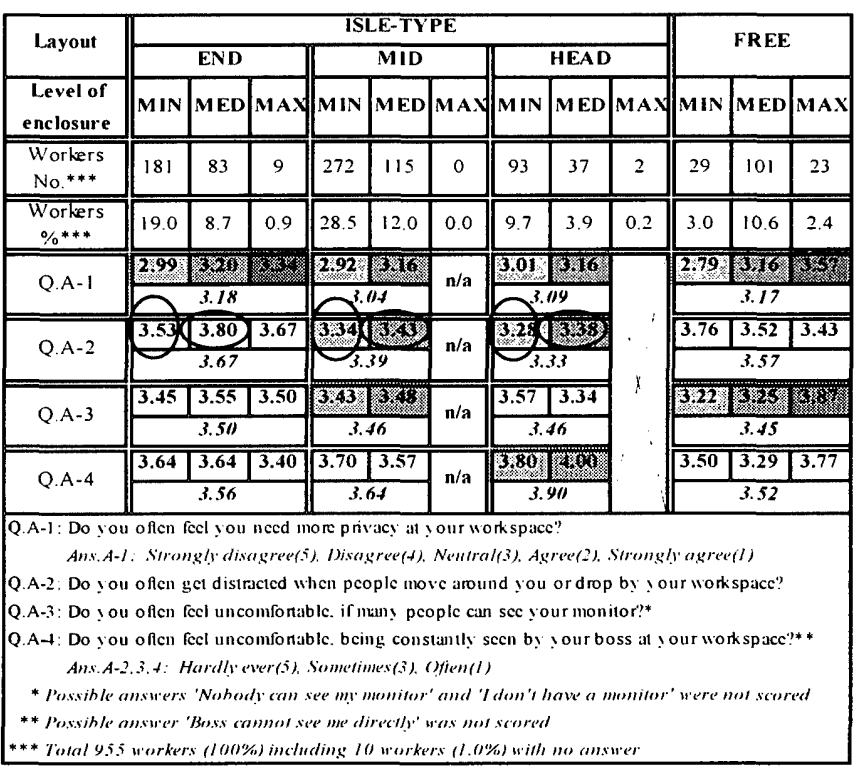

Table 6. Mean values for visual privacy cross-tabulated by layout/seating and enclosure 


\subsubsection{Visual Privacy Issues}

Perceived visual privacy was investigated with 4 questions in the questionnaire (see Table 6). Answers were measured with 3 and 5 point Likert scales and were all reverse-scored from 5-1; that is, a lower value indicating less visual privacy. Using the 945 sample, mean values were calculated and cross-tabulated by layout/seating and enclosure types.

Shaded areas in Table 6 indicate, that - seating position being constant - as enclosure level increases, so does the level of perceived visual privacy (darker areas indicating higher privacy levels). The 'need for privacy' variable (Q.A-1) showed this tendency most clearly. In Table 6, circles indicate, that comparing mean values of different seating positions in the isle-layout with the same (MIN and MED) enclosure levels shows a tendency of decreasing visual privacy as we go from the END to the HEAD of the row. Comparing the average mean values of enclosure levels of each seating positions (printed in Italics) also showed a tendency of decreasing visual privacy level from END to HEAD positions, regarding to the 'distraction from people' variable (Q.A-2). However, the lowest mean value (3.56) among the three seating positions in the isle-type layout shows that workers at the END. of the row were more often uncomfortable when seen by their boss (see question A-4) than those in MID (mean value: 3.64 ) and END (mean value: 3.90 ) positions. The free layout showed the lowest visual privacy levels considering questions A-3 and A-4.

$42.4 \%(n=401)$ of all workers expressed their disagreement that it was important for their work to be constantly seen by their bosses (Q.B 1 in Table 7). However, among these workers only $24.1 \%$ reported that they could not be directly seen by their bosses; $11.0 \%$ felt often and $36.0 \%$ felt sometimes uncomfortable being constantly seen (Table 7).

\begin{tabular}{|c|c|c|c|c|c|c|c|c|c|}
\hline \multirow{3}{*}{ Q..B-I* } & \multicolumn{2}{|c|}{ SD } & \multicolumn{2}{|c|}{ D } & $\bar{N}$ & \multicolumn{2}{|c|}{$\mathbf{A}$} & \multicolumn{2}{|c|}{ SA } \\
\hline & \multicolumn{2}{|c|}{$\begin{array}{l}23.4 \% \\
(221)\end{array}$} & \multicolumn{2}{|c|}{$\begin{array}{l}19.0 \% \\
(180)\end{array}$} & $\begin{array}{l}23.9 \% \\
(226) \\
\end{array}$ & \multicolumn{2}{|c|}{$\begin{array}{l}24.4 \% \\
(230)\end{array}$} & \multicolumn{2}{|c|}{$\begin{array}{l}9.1 \% \\
(85)\end{array}$} \\
\hline & \multicolumn{4}{|c|}{$\begin{array}{l}+2 . f^{\prime \prime \prime} \\
(+01)\end{array}$} & & \multicolumn{4}{|c|}{$\begin{array}{l}33.5 \% \\
(315)\end{array}$} \\
\hline \multirow{3}{*}{$\left(O . B=2^{* *}\right.$} & $\mathrm{HE}$ & $S$ & $\mathrm{O}$ & B & & $\mathrm{HE}$ & $\mathrm{S}$ & $\mathrm{O}$ & $\mathrm{B}$ \\
\hline & $28.9 \%$ & $36.0 \%$ & $11.0 \%$ & $24.1 \%$ & & $43.2 \%$ & $39.8 \%$ & $10.6 \%$ & $6.4 \%$ \\
\hline & $(116)$ & L(144) & (44) & (97) & & (136) & (125) & (33) & $(21)$ \\
\hline \multirow{2}{*}{\multicolumn{10}{|c|}{ 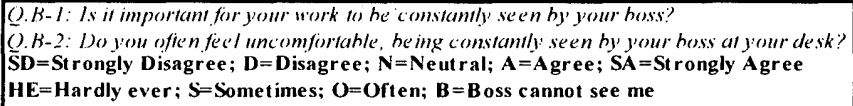 }} \\
\hline & & & & & & & & & \\
\hline \multicolumn{10}{|c|}{$\begin{array}{l}\text { Values in pare ntheses indicate number of worke } \\
\text { * Total: } 9+5(100 \% 11 \text { - with } 3 \text { no answers })\end{array}$} \\
\hline
\end{tabular}

Table 7. Visual privacy from boss

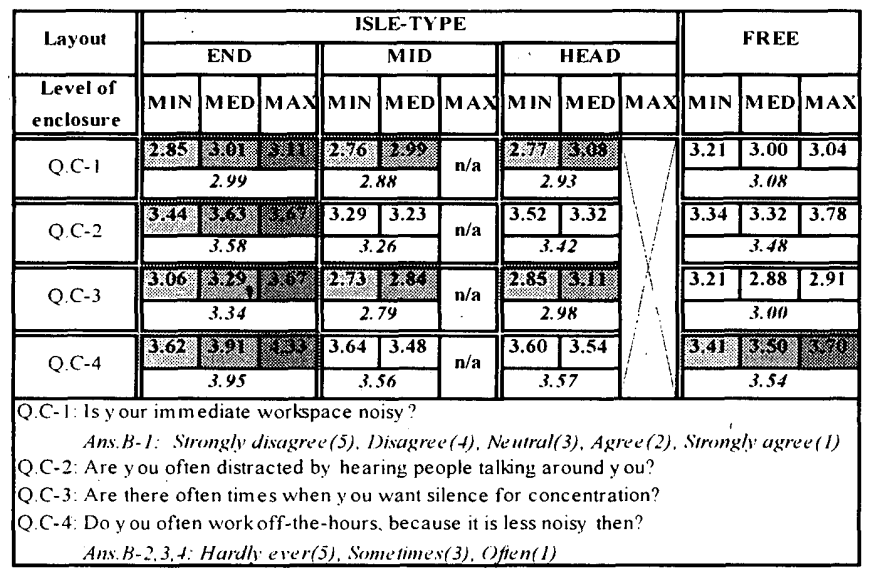

Table 8. Mean values for acoustical privacy cross-tabulated by layout/seating and enclosure (Database is the same as in Table 6. See workers' number and \% there)

\subsubsection{Acoustical Privacy Issues}

Table 8 shows the mean values for acoustical privacy. Categories of the physical workspace and meanings of the mean values as well as the database are the same as it was discussed at the visual privacy issues (Section 4.2.2). Similarly to visual privacy, acoustical privacy was also affected by the enclosure level.

In Table 8, shaded areas indicate increasing levels of acoustical privacy, as the individual enclosure level increases with seating positions being constant. In case of seating position at the END of the row, all variables show this tendency. In case of free layout, only the variable of Q.C-4 shows the same tendency.

Perceived noise level was the lowest in case of free layout (an average mean value of 3.08 - Q.C-1). Generally speaking, perceived noise distractions were the worst in case of MID and HEAD positions, and showed very similar average mean values in case of the END and FREE categories.

$42.3 \%(n=400)$ of all workers reported that their immediate workspaces were noisy (Q.D-1 in Table 9). Among this large number of workers, only $10.4 \%$ agreed strongly and $28.5 \%$ agreed that they could fully concentrate on their work despite the noise, while $26.8 \%$ disagreed, and $6.8 \%$ strongly disagreed (Table 9).

\subsubsection{Ease of and Ways of Communication Issues}

The 12 physical environmental categories were cross-tabulated with 2 communication variables (Table 10) using the same database as before. The meanings of the mean values are also the same as before, with higher values indicating getting more information. However, since straight questions were asked, no reverse-coding were necessary (1-5 scale)

Comparing to visual/acoustical privacy issues, the easiness of getting information shows reverse tendency: as enclosure increases while seating positions being constant, mean values for getting enough information decrease (see shaded areas in Table 10). Comparing seating positions in the isle-layout with constant.enclosure levels (MIN and

\begin{tabular}{|c|c|c|c|c|c|c|c|c|c|c|c|}
\hline \multirow{3}{*}{$\begin{array}{c}\text { Q.D-1 } \\
*\end{array}$} & \multicolumn{3}{|c|}{ SD } & \multicolumn{2}{|c|}{ D } & $\overline{\mathbf{N}}$ & \multicolumn{2}{|c|}{$\bar{A}$} & \multicolumn{3}{|c|}{ SA } \\
\hline & \multicolumn{3}{|c|}{$\begin{array}{c}10.2 \% \\
(96)\end{array}$} & \multicolumn{2}{|c|}{$\begin{array}{l}19.7 \% \\
(186)\end{array}$} & $\begin{array}{l}27.6 \% \\
(261)\end{array}$ & \multicolumn{2}{|c|}{$\begin{array}{l}34.0 \% \% \\
(321)\end{array}$} & \multicolumn{3}{|c|}{$\begin{array}{l}8.3 \% \\
(79)\end{array}$} \\
\hline & \multicolumn{5}{|c|}{$\begin{array}{r}29.9 \% \\
(282)\end{array}$} & & \multicolumn{5}{|c|}{$\begin{array}{r}+2.3 \% \\
(+f(\%)\end{array}$} \\
\hline \multirow{2}{*}{ Q.D-2 } & SD & D & $\mathrm{N}$ & $\mathrm{A}$ & $\mathrm{SA}$ & & SD & D & $\mathrm{N}$ & $\mathrm{A}$ & $\mathrm{SA}$ \\
\hline & $7.4 \%$ & $24.8 \%$ & $24.6 \%$ & $32.6 \%$ & $10.6 \%$ & & $6.8 \%$ & $26.8 \%$ & $27.5 \%$ & $28.5 \%$ & $\begin{array}{c}10.4 \% \\
(42)\end{array}$ \\
\hline \multicolumn{12}{|c|}{$\begin{array}{l}\text { Q.D-1: Is y our imm ediate workspace noisy? } \\
\text { Q.D-2: Can y ou fully concentrate on y our work even if it is noisy around y ou?* } \\
\text { SD=Strongly Disagree; D=Disagree; } \mathbf{N}=\text { Neutral; } \mathbf{A}=\mathbf{A g r e e} ; \mathbf{S A}=\text { Strongly Agree }\end{array}$} \\
\hline \multicolumn{12}{|c|}{$\begin{array}{l}\text { Values in pare nheses indicate number of workers } \\
\text { * Tital: } 945(100 \%-\text { with } 2 \text { no answe rs) } \\
* * \text { Toral: } 282(100 \%) \text { and } 400(100 \%)\end{array}$} \\
\hline
\end{tabular}

Table 9. Noise and concentration

\begin{tabular}{|c|c|c|c|c|c|c|c|c|c|c|c|c|}
\hline \multirow{3}{*}{$\begin{array}{c}\text { Layout } \\
\text { Level of } \\
\text { enclosure }\end{array}$} & \multicolumn{9}{|c|}{ ISLE-TYPE } & \multirow{2}{*}{\multicolumn{3}{|c|}{ FREE }} \\
\hline & \multicolumn{3}{|c|}{ END } & \multicolumn{3}{|c|}{ MID } & \multicolumn{3}{|c|}{ HEAD } & & & \\
\hline & MIN & MED & MAX & M IN & MED & MAX| & MIN & M ED & & MIN & MED & $\mathbf{M A X}$ \\
\hline \multirow{2}{*}{ Q.E-I } & 3.59 & 3.80 & 3.44 & 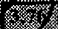 & 6.62 & \multirow{2}{*}{$\mathrm{n} / \mathbf{a}$} & & \multirow{2}{*}{$\frac{1866}{77}$} & \multirow{4}{*}{1} & 3.72 & 3.55 & 3.74 \\
\hline & \multicolumn{3}{|c|}{3.61} & \multicolumn{2}{|c|}{3.69} & & & & & \multicolumn{3}{|c|}{3.67} \\
\hline \multirow{2}{*}{ Q.E-2 } & rox & 821 & 2.13 & $8 \%$ & 393 & \multirow{2}{*}{ n/a } & \multirow{2}{*}{\multicolumn{2}{|c|}{$\frac{1}{3.23}$}} & & $\longdiv { 3 . 3 1 }$ & 3.08 & 3.36 \\
\hline & & 2.67 & & 3. & & & & & & & 3.25 & \\
\hline & & & & & & & & & & & & \\
\hline
\end{tabular}

Table 10. Mean values for communication cross-tabulated by layout/seating and enclosure (Database is the same as in Table 6. See workers' number and \% there) 


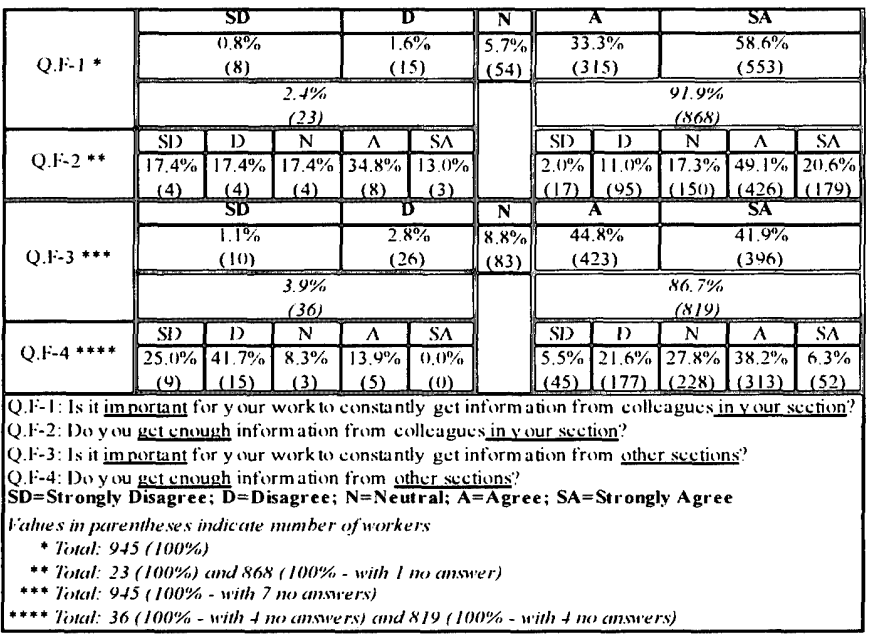

Table 11. Importance of getting information

MED - see circled values), getting enough information becomes easier as we go from END to HEAD positions. In case of getting information from other sections, people with free layout reported the highest values.

91.9\% (868) of all workers reported that it was important for their work to constantly get information from colleagues in their section (Q.F-1 in Table 11). Among these workers however, only about twothird reported that they actually got enough information (see Table 11 for details). Similarly, $86.7 \%$ of all workers reported the importance of constantly getting information from other sections, while only less than half of them actually reported getting enough information (see Table 11 for details).

Next, important ways of getting information from one's own section and from other sections were investigated with two multiplechoice questions in the questionnaire, where workers could choose one or more answers (Table 12). Possible answers of 'face-to-face talking' and 'leaving notes' were grouped under the category 'Personally'. Similarly, 'via e-mail' and 'via computer information system' answers were grouped: 'Via computer'. Here, only the two office layouts (without seating positions) were distinguished with enclosure levels for cross-tabulations. While phone or electronic communication was obviously not affected by physical characteristics, a surprising finding was that regardless to office layout or enclosure level, personal communication was prevailing in case of in-section communication.

\begin{tabular}{|c|c|c|c|c|c|c|c|c|c|}
\hline \multirow{2}{*}{ 产 } & \multirow{2}{*}{ 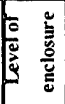 } & \multicolumn{2}{|c|}{ Workers } & \multicolumn{3}{|c|}{ From own section } & \multicolumn{3}{|c|}{ From other sections } \\
\hline & & No. & $\%$ & Personally & By phone & $\begin{array}{c}\text { Via } \\
\text { computer }\end{array}$ & Personally & By phone & $\begin{array}{c}\text { Via } \\
\text { computer }\end{array}$ \\
\hline \multirow{3}{*}{$\mid \begin{array}{l}\frac{2}{2} \\
\frac{2}{2}\end{array}$} & MIN & 546 & 57.2 & $\begin{array}{l}96.0 \% \\
(524)\end{array}$ & $\begin{array}{l}22.7 \% \\
(124) \\
\end{array}$ & $\begin{array}{l}57.0 \% \\
(311) \\
\end{array}$ & \begin{tabular}{|l}
$71.8 \%$ \\
$(392)$ \\
\end{tabular} & $\begin{array}{l}53.1 \% \\
(290) \\
\end{array}$ & $\begin{array}{l}73.3 \% \\
(400)\end{array}$ \\
\hline & MED & 235 & 24.6 & $\begin{array}{l}97.0 \% \\
(228)\end{array}$ & $\begin{array}{c}16.2 \% \\
(38)\end{array}$ & $\begin{array}{l}57.9 \% \\
(136)\end{array}$ & $\begin{array}{l}73.6 \% \\
(173)\end{array}$ & $\begin{array}{l}44.3 \% \\
(104)\end{array}$ & $\begin{array}{l}74.0 \% \\
(174)\end{array}$ \\
\hline & MAX & 11 & 1.2 & $\begin{array}{c}100.0 \% \\
\text { (11) }\end{array}$ & $\begin{array}{c}18.2 \% \\
(2)\end{array}$ & $\begin{array}{c}63.6 \% \\
(7)\end{array}$ & $\begin{array}{c}63.6 \% \\
(7)\end{array}$ & $\begin{array}{c}45.5 \% \\
(5)\end{array}$ & $\begin{array}{c}81.8 \% \\
(9)\end{array}$ \\
\hline \multirow{3}{*}{$\mid \begin{array}{l}\frac{1}{\sqrt{2}} \\
\frac{\alpha}{2} \\
\frac{1}{2}\end{array}$} & MIN & 29 & 3.0 & $\begin{array}{c}100.0 \% \\
(29)\end{array}$ & $\begin{array}{c}24.1 \% \\
(7)\end{array}$ & $\begin{array}{c}65.5 \% \\
(19)\end{array}$ & $\begin{array}{c}82.8 \% \\
(24)\end{array}$ & $\begin{array}{c}44.8 \% \\
(13)\end{array}$ & $\begin{array}{c}82.8 \% \\
(24)\end{array}$ \\
\hline & MED & 101 & 10.6 & $\begin{array}{c}90.1 \% \\
(91)\end{array}$ & $\begin{array}{c}20.8 \% \\
(21)\end{array}$ & $\begin{array}{c}64.4 \% \\
(65)\end{array}$ & $\begin{array}{c}75.2 \% \\
(76)\end{array}$ & $\begin{array}{c}41.6 \% \\
(42)\end{array}$ & $\begin{array}{c}85.1 \% \\
(86)\end{array}$ \\
\hline & MAX & 23 & 2.4 & $\begin{array}{r}95.7 \% \\
(22)^{\prime} \\
\end{array}$ & $\begin{array}{c}34.8 \% \\
(8)\end{array}$ & $\begin{array}{l}73.9 \% \\
(17)\end{array}$ & $\begin{array}{l}65.2 \% \\
(15)\end{array}$ & $\begin{array}{c}60.9 \% \\
(14)\end{array}$ & $\begin{array}{l}82.6 \% \\
(19)\end{array}$ \\
\hline & $\begin{array}{l}\text { no } \\
\text { siver: }\end{array}$ & 10 & 1.0 & \multirow{2}{*}{\multicolumn{6}{|c|}{ 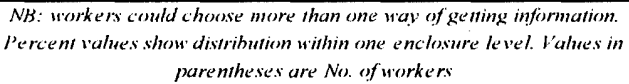 }} \\
\hline & otal: & 955 & 100 & & & & & & \\
\hline
\end{tabular}

Table 12. Important ways of getting information from own section and from other sections
Intersectional communication was rather done by e-mail or telephone; however, percentage of personal communication was still very high (see Table 12).

\subsubsection{Users' Needs for Changes}

To the question: 'Do you want to move to another workspace?', workers gave answers on a 5 point Likert scale (see Table 13) and those who strongly agreed $(8.3 \%)$ or agreed $(9.5 \%)$ were asked to indicate their reasons with free answers. The reasons with considerable frequencies are reported in the lower part of Table 13. Most workers wanted to move because of noise, unable to concentrate and lack of privacy (workers could write more than one reason).

Finally, a question (free answer) asked workers: 'What would you change in your office in an event of a future remodeling in ord er to have a better work environment?' The response rate to this question was $66.7 \%$ (684 workers), and among these, $92.0 \%$ (629 workers) wanted to improve their environment somehow (while only $8.0 \%$ of them

\begin{tabular}{|c|c|c|c|c|c|}
\hline & \multicolumn{5}{|c|}{ Do you want to move to another workspace? } \\
\hline & St rongly agree & Agree & Neutral & Disagree & $\begin{array}{l}\text { Strongly } \\
\text { disagree }\end{array}$ \\
\hline$\%$ of all workers: & $\overline{8.3}$ & 9.5 & $\overline{38}$ & $\overline{19.6}$ & $\overline{24.3}$ \\
\hline No. of workers: * & 83 & 97 & 390 & 201 & 252 \\
\hline $\begin{array}{c}\text { Reasons why workers } \\
\text { wanted to move }\end{array}$ & $\begin{array}{l}6 \text { of the } 8.3 \\
\text { norkers }\end{array}$ & $\begin{array}{l}\text { \%o of the } 97 \\
\text { norkers }\end{array}$ & & & \\
\hline not enough space & $\overline{8.2}$ & 13.4 & & & \\
\hline Want different layout & 4.9 & 5.0 & & & \\
\hline $\begin{array}{l}\text { Want corrier } \\
\text { windowses }\end{array}$ & 8.2 & 12.2 & & & \\
\hline don't feel at ease & 14.8 & 15.6 & & & \\
\hline hekof privacyl & & & & & \\
\hline $\begin{array}{l}\text { ancomior rable to be } \\
\text { constiuly seen }\end{array}$ & & & & & \\
\hline bad personal relations & 8.2 & 1.2 & & & \\
\hline $\begin{array}{l}\text { hoisy/dish uptions by } \\
\text { otherst cunnot } \\
\text { concent rate }\end{array}$ & 26.2 . & 25.6 & & & \\
\hline $\begin{array}{l}\text { unpleasant } \\
\text { temperature or smelly }\end{array}$ & 3.3 & 4.9 & & & \\
\hline
\end{tabular}

Table 13. Why workers wanted to change their workspaces $\left({ }^{*} n=3\right.$ workers did not answer. Shaded areas indicate related issues to this article.)

\begin{tabular}{|c|c|c|c|}
\hline Categories & What workers wanted & No. & $\%$ \\
\hline storage & more/larger/better org. storage & 154 & 22.6 \\
\hline \multirow{3}{*}{$\begin{array}{l}\text { air quality /natural } \\
\text { lighulighting }\end{array}$} & better $A C$ & 83 & 12.2 \\
\hline & natural light/able to see/open window & 56 & 8.2 \\
\hline & more light & 23 & 3.4 \\
\hline \multirow{2}{*}{ space } & larger workspace/table & 75 & 11.0 \\
\hline & more spacious office/passages & 54 & 7.9 \\
\hline common spaces & more/better $m$ eeting tables/room s\& com mon spaces & 70 & 10.3 \\
\hline \multirow{2}{*}{ privacylonise } & higher or nore partilion & 32. & M47.2. \\
\hline & wore pr wacy/noise controlplaces for concentration & $54 \%$ & 7.98 \\
\hline \multirow{2}{*}{ orricerfornitire } & Change of fice layout to better, nore functional & 88 & 12.9 \\
\hline & Tovertiess partitions : & 6 & 090 \\
\hline \multirow{3}{*}{$\begin{array}{l}\text { secondary spaces } \\
\& \text { services }\end{array}$} & more places to relax, rest and drink & 85 & 12.5 \\
\hline & /larger/better toilets/locker rooms & 21 & 3.1 \\
\hline & $\begin{array}{l}\text { better/more facility services (kitchene'tre, vending } \\
\text { machines firdges) }\end{array}$ & 9 & 1.3 \\
\hline \multirow{4}{*}{$\begin{array}{l}\text { office } \\
\text { environment/interio } \\
r \text { design/ergonomics }\end{array}$} & better environment/full renewal & 22 & 3.2 \\
\hline & better office design/interior decoration & 32 & 4.7 \\
\hline & better ergonom ics, new/com fortable furniture & 14 & 2.1 \\
\hline & plants & 18 & 2.6 \\
\hline \multirow[t]{2}{*}{ office technology } & $\begin{array}{l}\text { better/more/faster office machines, OAcorner, } \\
\text { networks, ITsy stems }\end{array}$ & 40 & 5.9 \\
\hline & $\mathrm{OA}$ floor/elim ination of open wiring & 17 & 2.5 \\
\hline \multirow{2}{*}{$\begin{array}{l}\text { management/other } \\
\text { FM problems }\end{array}$} & better/separated smoking places/non-sm oking office & 46 & 6.8 \\
\hline & other related organizational $/ \mathrm{m}$ anage $\mathrm{m}$ ent $/ \mathrm{FM}$ issues & 22 & 3.2 \\
\hline \multicolumn{2}{|l|}{ others/not clear } & 9 & 1.3 \\
\hline \multicolumn{2}{|l|}{ no needs, good as it is } & 55 & 8.1 \\
\hline
\end{tabular}

Table 14. What workers wanted for a better working environment (Shaded areas indicate related issues to this article) 
considered their workplaces 'good as it is'): Mentioning an improvement issue counted as one item; many workers wrote more than one item. Items were counted, and those with considerable frequencies are reported in Table 14. Many people wanted to change their office layout, wanted more privacy, or wanted higher or more partitions.

\subsubsection{Correlations with Productivities}

Pearson product-moment correlation coefficients were calculated to investigate the relationships of the psychophysical variables (questions A-1 to A-4, C-1 to C-4 and E-1 to E-2 - see Tables 6,8,10), and 6 productivity (work performance) variables from the questionnaire.

\begin{tabular}{|c|c|c|c|c|c|c|c|c|c|}
\hline Q.No. & 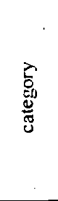 & name of variable & 5 & 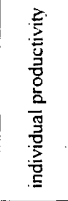 & 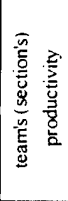 & 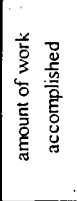 & 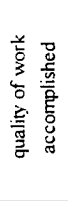 & 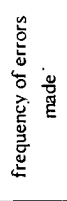 & 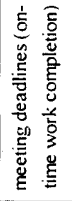 \\
\hline Q.A-1 & \multirow{4}{*}{ 氚 } & need privacy & $\begin{array}{l}r \\
n\end{array}$ & $\begin{array}{l}.021 \\
943\end{array}$ & $\begin{array}{l}102 \% \\
940\end{array}$ & $\begin{array}{l}001 \\
942\end{array}$ & $\begin{array}{l}079^{*} \\
941\end{array}$ & $\begin{array}{c}.069^{*} \\
943\end{array}$ & $\begin{array}{c}.077^{*} \\
937\end{array}$ \\
\hline Q.A-2 & & \begin{tabular}{|c|} 
distraction from \\
people
\end{tabular} & $\bar{r}$ & $\begin{array}{l}.017 \\
943\end{array}$ & $\begin{array}{l}088^{-7} \\
.940\end{array}$ & $\begin{array}{l}-.048 \\
942\end{array}$ & $\begin{array}{l}.046 \\
941\end{array}$ & $\begin{array}{l}.049 \\
943\end{array}$ & $\begin{array}{l}909 \times 7 \\
937\end{array}$ \\
\hline Q.A.3 & & $\begin{array}{c}\text { monitor seen by } \\
\text { people }\end{array}$ & $\begin{array}{l}n \\
n\end{array}$ & $\begin{array}{l}087^{\circ} \\
884\end{array}$ & $\begin{array}{l}090 * 72 \\
882\end{array}$ & $\begin{array}{l}.070^{*} \\
883^{\circ}\end{array}$ & $\begin{array}{l}088^{* 7} \\
882\end{array}$ & \begin{tabular}{|l}
.065 \\
884
\end{tabular} & $\begin{array}{l}.036 \\
878\end{array}$ \\
\hline Q.A-4 & & $\begin{array}{c}\text { constantly seen } \\
\text { by boss }\end{array}$ & $\begin{array}{l}r \\
n\end{array}$ & $\begin{array}{l}1.149^{*} \\
799\end{array}$ & $\begin{array}{l}.070^{*} \\
798\end{array}$ & $\begin{array}{l}.088^{*} \\
798 \\
\end{array}$ & $\begin{array}{l}1717 \% \\
797\end{array}$ & $\begin{array}{l}132 * \\
799\end{array}$ & $\begin{array}{l}102^{*} \\
795\end{array}$ \\
\hline Q.B-1 & \multirow{4}{*}{ 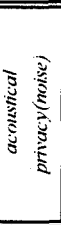 } & $\begin{array}{c}\text { noisiness of } \\
\text { workspace }\end{array}$ & $\begin{array}{l}r \\
n\end{array}$ & $\begin{array}{l}-.002 \\
942\end{array}$ & $\begin{array}{l}070^{*} \\
939\end{array}$ & $\begin{array}{l}109^{9} \\
941\end{array}$ & $\begin{array}{l}.001 \\
940\end{array}$ & $\begin{array}{c}-.019 \\
942\end{array}$ & $\begin{array}{l}712^{* * 2} \\
936\end{array}$ \\
\hline Q.B-2 & & $\begin{array}{l}\text { unwanted noise } \\
\text { (people talking) }\end{array}$ & $\begin{array}{l}\mathrm{r} \\
\mathrm{n}\end{array}$ & $\begin{array}{c}-.007 \\
942\end{array}$ & $\begin{array}{l}.07 .1^{*} \\
940\end{array}$ & $\begin{array}{l}-.060 \\
941\end{array}$ & $\begin{array}{c}-.011 \\
940\end{array}$ & $\begin{array}{l}.040 \\
942\end{array}$ & $\begin{array}{l}.082^{*} \\
936\end{array}$ \\
\hline Q.B-3 & & $\begin{array}{c}\text { want silence for } \\
\text { concentration }\end{array}$ & $\begin{array}{l}\mathrm{r} \\
\mathrm{n}\end{array}$ & $\begin{array}{c}-.042 \\
944\end{array}$ & $\begin{array}{l}.075 * \\
941\end{array}$ & $\begin{array}{l}094^{77} \\
943\end{array}$ & $\begin{array}{c}-.062 \\
942\end{array}$ & $\begin{array}{l}.009 \\
944\end{array}$ & $\begin{array}{l}167 \% \\
938\end{array}$ \\
\hline Q.B-4 & & $\begin{array}{c}\text { stay late when } \\
\text { less noisy }\end{array}$ & $\bar{r}$ & $\begin{array}{c}-.053 \\
939 \\
\end{array}$ & $\begin{array}{l}.039 \\
936 \\
\end{array}$ & $\begin{array}{l}176^{\circ} \\
938^{\circ} \\
\end{array}$ & $\begin{array}{c}-.055 \\
937 \\
\end{array}$ & $\begin{array}{l}085 \% 7 \\
939 \\
\end{array}$ & $\begin{array}{c}308^{* *} \\
933\end{array}$ \\
\hline Q.C-I & \multirow{2}{*}{ 章 } & $\begin{array}{c}\text { enough info from } \\
\text { own section }\end{array}$ & $\bar{r}$ & $\begin{array}{l}127^{77} \\
943\end{array}$ & $\begin{array}{l}2,22^{* 1} \\
940\end{array}$ & $\begin{array}{l}097^{7} \\
942\end{array}$ & $\begin{array}{l}1097 \\
941\end{array}$ & $\begin{array}{c}-.005 \\
943\end{array}$ & $\begin{array}{l}117^{67} \\
937\end{array}$ \\
\hline Q.C-2 & & $\begin{array}{c}\text { enough info from } \\
\text { other sections }\end{array}$ & $\mathrm{r}$ & $\begin{array}{l}145 * 7 \\
922\end{array}$ & $\begin{array}{l}183^{* *} \\
919\end{array}$ & $\begin{array}{l}106^{\circ} \\
921\end{array}$ & $\begin{array}{l}111 \% * \\
920\end{array}$ & $\begin{array}{c}-.007 \\
922\end{array}$ & $\begin{array}{c}-.036 \\
916\end{array}$ \\
\hline
\end{tabular}

Table 15. Correlation matrix of psychophysical and productivity variables ( $r=$ Pearson product-moment correlation coefficient; $n=$ No. of valid data pairwise cases were excluded painvise for missing values)

**Correlation is significant at the 0.01 level (2-tailed)

Significant correlation values are shaded in Table 15.

Visual privacy showed significant positive correlations with most of the productivity variables: 'discomfort from monitor seen by others' strongly correlated with the 'individual' and 'team productivity', as well as the 'quality of work accomplished' variables. 'Discomfort from constantly seen by boss' significantly positively correlated with 'individual productivity', 'quality of work', 'frequency of errors made' and 'on-time work completion' variables.

Acoustical privacy (noise) mostly affected 'on-time work completion', somewhat affected 'frequency of errors made', but was surprisingly significantly negatively correlated with 'amount of work accomplished' and did not significantly correlate with any other productivity variables.

Variables of 'getting enough information from own section' and 'getting enough information from other sections' showed significant positive correlations with almost all productivity variables, while obviously they did not correlate with the 'frequency of errors made' variable.

\section{Conclusion}

Most of the findings of group interviews were confirmed by the quantitative data of the questionnaires.

Comparing isle-type layout and free layout did not show much difference in privacy or noise issues, however, the latter one seems to allow better intersectional communication.

Considering seating positions in the isle-layout, people at the end of the row could get more visual or acoustical privacy, than those sitting at the middle or at the head of the isle. Getting information showed reverse tendency: those sitting at the end of the row got considerably less information from their own or other sections.

Enclosure levels had the strongest mediating effects on privacy and communication: as partitions' number and height increased, perceived visual privacy also increased, and distraction from noise decreased; however, the ability to get enough information also decreased. The latter one is probably because regardless to the layout or enclosure level, most of the workers communicated personally.

Regardless to physical characteristics, almost half of all workers thought their workplace was noisy. Among them, one third reported lack of concentration on their work. About one third of workers who had minimum enclosure around their workspaces wanted more or higher partitions. Almost half of all the workers felt it unnecessary for they work to be seen by their bosses, and among them, almost half reported discomfort being constantly seen. Almost $20 \%$ of all workers wanted to change their workplaces: noise and privacy complaints were the most common reasons. Most of those who wanted a better work environment mentioned the need for changing the layout to a better, more functional one.

The correlation analyses proved some of our hypotheses: ease of communication affected workers' productivity the most. Also, visual privacy significantly positively correlated with almost all variables of productivity. However, oppositely to our hypothesis, noise showed very little effect on productivity, and it was negatively correlated with the amount of work one accomplished.

In summary, we note that in our study a carefully designed a mount of enclosure around individual workspaces turned out to be important. Some level of enclosure was necessary for privacy; however, too much enclosure could hinder productivity and face-to-face communication. Noise, though in our study did not affect productivity, was a serious issue.

\section{Notes}

a) Brill et al. (1984) ${ }^{3)}$ and the writers of this paper call these 'psychophysical factors'.

b) Brill et al. (2001) 4) defines "workspace" as "the space where an employee sits (mostly) when in the office" as opposed to 'workplace', "a general term for the entire physical environment for work ..."

c) Landscape offices were originated in Germany in the 50's and were called "Bürolandschaft".

d) Brill et al. (2001) ${ }^{4}$ ' warn that 'systems furniture' and 'open office' are not interchangeable terms: "Systems furniture is furniture and panel units whose dimensions, geometries, and connections are pre-engineered for compatibility."

e) The 'isle-type layout' is called 'obeya-shimagata' in Japanese. In this study we define 'isle-type layout' as workers facing each other in a row of desks, which are laid out in a neat order, forming several isles in a large, open room with desks at the head of each isle looking towards the row (see Figures 2 and 3).

f) In this study, we define 'free layout' as an open office with individual workspaces laid out in a free order, as opposed to the strict layout of the 'isle-type'. Free layout is different from the landscape-office, as the first one does not necessarily integrate systems-furniture and partitions (see Figure 4).

g) Kupritz $(2003)^{24)}$ refers 'speech or conversational privacy' to "a person's ability to 

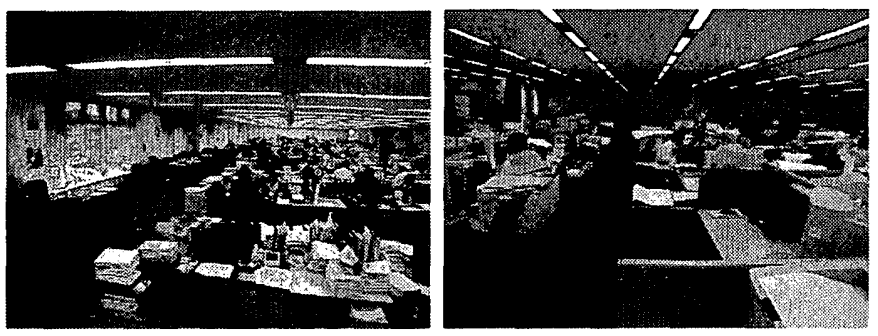

Figure 2. Isle-lype layoul with no partitions around workspaces

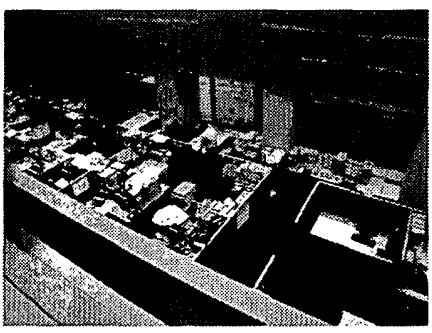

Fïgure 4. Frec-layout with medium

partitions around 3 sides of workspaces

hold conversations inside a workspace without being overheard and understood by people outside the workspace."

h) According to Kupritz $(2003)^{24)}$, 'acoustical privacy " includes speech privacy and isolation from environmental background noise."

i) Kupritz (2003) ${ }^{24)}$ defines 'visual privacy' as "isolation from unwanted observation."

j) BOSTI - Buffalo Organization for Social and Technological Innovations

k) The floor plans and some of the pictures were asked to remain confidential.

l) Out of the $6.9 \%$ 'other' category, $0.7 \%$ worked in isle-type layout but did not check the ir seating positions, $2.1 \%$ worked in 'fishbone-layout' (in an open office, desks are facing in one direction, with a long, common table between desks), $3.1 \%$ had desks in small groups in their offices and the rest, $0.9 \%$ were not specified

\section{References}

1) Brennan, A., Chugh, J.S., and Kline, T.: Traditional Versus Open Office Design: A Longitudinal Field Study. Environment and Behavior, Sage Publications, Vol.34(3) pp.279-299, 2002

2) Kupritz, V.W.: The Role of the Physical Environment in Maximizing Opportunities for the Aging Workforce. Journal of Industrial Teacher Education, Vol.37(2), pp.66-88, 2000

3) Brill, M., Margulis, S., and Konar, E.: Using Office Design to Increase Productivity. Workplace Design and Productivity, Buffalo, NY, 1984

4) Brill, M., Weidemann, S., and the BOSTI Associates: Disproving Widespread Myths ahout Workplace Design. Kimball International, 2001

5) Zahn, L.G.: Face to Face Communication in an Office Selting: The Effects of Position, Proximity and Exposure. Communication Research, Vol.18, pp.737-754, 1991

6) Oldham, G.R., and Brass, D.J.: Employee Reactions to an Open-Plan Office: A Naturally-Occurring Quasi-Experiment. Administrative Science Quarterly, Vol.28, pp.267-284, 1979

7) Ellis, P., and Duffy, F.: Lost office landscapes. Management Today, pp. 47, May, 1980

8) Boyce, P.R.: Users' Assessments of a Land scaped Office. Journal of Architectural Rescarch, Vol.3(3), pp.44-62, 1974

9) Brookes, M.J., and Kaplan, A.: The Office Environment: Space Planning and Affective Behavior. Human Factors, Vol.14(5), pp.373-391, 1972

10) Zeitlin, L.R.: A comparison of employee attitudes toward the conventional office and the landscaped office. Organization and Procedures Department, Port Authority of New York, NY, 1969

11) Hedge, A.: The open-plan office: A systematic investigation of employee reactions to their work environment. Environment and Behavior, Sage Publications,
Vol.14(5), pp.519-542, 1982

12) Canter, D.V.: Reactions to Open Plan Offices. Built Environment, Vol.1(Oct), pp.465-467, 1972

13) Sundstrom, E.: Crowding as a Sequential Process: Review of Research on the Effects of Density on Humans. In A. Baum \& Y.M. Epstein (Eds.), Human Response to Crowding, pp. 31-116, Lawrence Erlbaum, Hillsdale, NJ, 1978

14) Rader, M., and Gilsdorf, J.: Preventing environmental stress in the open office. Journal of Systems Management, Vol.32(3), pp.25, 1981

15) Oldham, G.R.: Effects of Changes in Workspace Partitions and Spatial Density on Employee Reactions: A Quasi-Experiment. Journal of Applied Psychology, Vol.73., pp. $253-258,1988$

16) Oldham, G.R. and Rotchford, N.L.: Relationships Between Office Characteristics and Employee Reactions: A Study of the Physical Environment. Administrative Science Quarterly, Vol.28, pp.542-556, 1983

17) Sundstrom, E., Burt, R.E., and Kamp, D.: Privacy at Work: Architectural Correlates of Job Satisfaction and Job Performance. Academy of Management Journal, Vol.23(1), pp.101-117, 1980

18) O'Neill, M.J.: Work Space Adjustability, Storage, and Enclosure as Predictors of Employee Reactions and Performance. Environment and Bchavior, Sage Publications, Vol.24(4), pp.504-526, 1994

19) Akiyama, K., Wada, T., Inui, M., and Nakamura, Y.: Interpersonal factors influencing the evaluation of office environments. Journal of Archit.Plann.Environ.Eng., AIJ, No. 474, pp.65-73, Aug., 1995

20) Boje, A.: Open Plan Offices. Business Books, London, 1971

21) Pile, J.F.: Open Office Planning: A Handhook for Interior Designers and Architects. Architectural Press, London, 1978

22) Sundstrom, E.: Work Places: The Psychology of the Physical Environment in Offices and Factories. Cambridge University Press, New York, 1986

23) Kupritz, V.W.: Privacy in the Work Place: The Impact of Building Design. Journal of Environmental Psychology, Academic Press, Vol.18(4), pp.341 -356, 1998

24) Kupritz, V.: Accommodating Privacy to Facilitate New Ways of Working. Journal of Architectural and Planning Research, Vol.20(2), Summer, 2003

25) Sundstrom, E., Town, J.P., Brown, D.W., and McGee, C.: Physical enclosure, type of job, and privacy in the office. Environment and Bchavior, Sage Publications, Vol.14(5), pp.543-559, 1982

26) Akiyama, K., Hirayama, T., Nakamura, Y., and Inui, M.: Privacy and communication in office environment evaluation. Journal of Archit.Plann.Environ.Eng., AlJ, No. 484, pp.94-107, Jun., 1996

27) Landy, F.J. and Trumbo, D.A.: Psychology of work hehavior. Dorsey Press, Homewood, IL, 1980

28) Harris, L. and Ass.: The Steelcase National Study of Office Emiromments: Do They Work? Steelcase, Inc., Grand Rapids, MI, 1978

29) Kahn, R. and Byosiere, P.: Stress in Organizations. In: Dunnette, M.D. and Hough L.M. (Eds.): Handhook of Industrial and Organizational Psychology $\left(2^{\text {nd }}\right.$ ed.) Vol.3., pp.571-650, Consulting Psychologists Press, Palo Alto, CA, 1992

30) Nemecek, J., and Grandjean, E.: Noise in landscaped offices. Applied Ergonomics, Vol.4(1), pp.19-22, 1973

31) Miura, T. and Miyao, K.: The correlations between measured physical levels and the occupants sensation responses at their offices. A study on indoor environment and comfort in offices based on synthetic investigations, Part 1. Journal of Archit.Plann.Environ.Eng., AIJ, No. 539, pp.89-96, Jan., 2001

32) Sundstrom, E., Town, J.P., Rice, R.W., Osborn, D.P., and Brill, M.: Office Noise and Satisfaction, and Performance. Environment and Bchavior, Sage Publications, Vol.26., pp.195-222, 1994

33) Takahashi, K., Sasaki, H., Saito, T., Hosokawa, T., Kurasaki, M., and Saito, K. Combined Effects of Working Environmental Conditions in VDT Work. Ergonomics, Vol.44(5), pp. 562-570, 2001

34) Ha, M., Kim, H-K., Je, H., and Min, B-H.: Office Environmental Satisfaction Focusing on Personal and Common Spaces. Journal of Asian Architecture and Building Engineering, Vol.1(2), pp. 165-170, November, 2002 


\section{和文要約}

1. 研究目的

本論は、オフィス環境に関する広範かつ複合的な研究の一部であ る。ワークプレースのデザイン・就業者の知覚・環境および仕事に 対する彼等の満足、ならびに生産性の間の関係性を描き出すための、 仮説的な総合的モデルを図 1 に示す。

日本のオフィス現況に詨する評価を通して、「生産的なワークプレ 一ス小計画の情報を得るために、本論は就業者の視覚的・聴覚的プ ライバシー並びにコミュニケーションについて検討する。それらは、 オフィスレイアウト・座席位置・ワークプレースの囲みによって媒 介されると示唆される。ノイズは生産性を阻害し、プライバシーと コミュニケーションのし易さは生産性を向上させると仮定される。

\section{2. 研究の背景}

\section{1. オフィスの物理的特性}

オープンオフィスに関する研究は相反する結果を示している。肯定

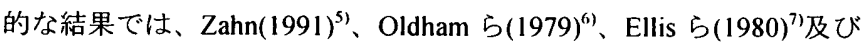
Boyce $(1974)^{\text {k) }}$ は、就業者間のコミュニケーションの向上を見い出し、 Brooks ら (1972) 9) は、相互交流の増加を報告している。否定的な結果 としては、就労者の環境的な不満足や作業遂行性能の低下（Oldham $1979^{(1)}$, Hedge $1982^{(1)}$, Canter $1972^{22)}$ )、心理的なプライバシーの水準 低下(Brookes ら 1972"), Hedge $1982^{\prime \prime \prime)}$ )、および作業の阻害 (Canter 1972 ${ }^{12)}$, Ellis ら $1980^{7)}$, Brookes ら $1972^{\circ)}$, Hedge $1982^{11)}$ ) が示されている。 ワークスペース間の仕切の数や高さ等の囲みのあり方について、 Brill ら(1984) ${ }^{3 !}$ は仕切の高さとプライバシー・コミュニケーション. 作業遂行性能との正の相関を見出し、Sundstrom ら(1980) ${ }^{17}$ は仕切の 高さが増すとプライバシー・ワークスペースの満足・作業遂行性能 が增寸ことを報告している。

\section{2.オフィスにおける心理物理的要因}

既往の研究は、就業者の心理的なプライバシーと建築的なプライ バシー(Sundstrom 1980) ${ }^{17)}$ とは連合していることを示している。 Kupritz(1998) ${ }^{23}$ | は、プライバシーの欠如がもたら寸視覚的・聴覚的阻 害は生産性を減じェラーを増すことを見出している。Brennan ら (2002) ”によるオープンオフィスに関寸る調査によれば、就業者の主 要苦情はブライバシー・・秘密の久如とノイズ増大である。

オフィス就業者にとって、ノイズは作業関連ストレスによる否定 的な影響をもたらし得るものとして樑刻な問題である(Kahn 1992) ${ }^{29)}$ 。

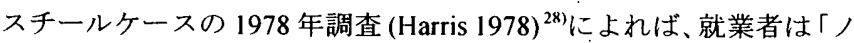
イズやその他の邪魔無しに集中出来ること」をオフイス環境におけ る 16 の指標の中で最も重要なものとして指摘している。Brill ら $(2001)^{\dagger)}$ の調査でも、「妨害なしの単独作業」が 10 項目の中で第 1 位 に挙げられている。' Boyce ら(1974) ${ }^{8)}$ は、オープンオフィスに働く就 業者の半分以上はソイズにようて妨害されており、ノイズの 55\%は 周りの人々の会話に依るとしている。しかし、Sundstrom ら (1994) ${ }^{32}$ は、ノイズと作業遂行性能との関連を見出していない。

適切なコミュニケーションは、家具・オフィスレイアウトによっ て影響される対人関係に関連する重要な側面の一つである(Ha ら $2002)^{3.4)}$ 。BOSTI (Brill ら 2001) ) $^{\text {) }}$ による最新の調查では、就業者の $87 \%$ は情報をインフォーマルに入手しているが、オープンオフィスに働
く者の $58 \%$ は、偶然耳にする他人の会話からは何も得ていない、と している。

\section{3. 研究の方法}

日本の建築設計主要組織の建築計画実務家への予備的インタビュ 一を行った上で、17 の大企業オフィス就業者に対する19のグループ インタビュー調査が行われた（参加者計 42 名）。ここで得られた結 果に基づいて、総合的質問紙調查が設計され、プリテストを経た上 で、日本の大都市にある 42 の様々な事業所の就業者 1,233 名に配布 され、1,039名の回答（回収率 $84.3 \%$ ）を得た（表 1,2 ）。

\section{4. 結果と考察}

インタビュー調査における結果の多くは質問紙調查による定量的 データによって確認された。大部屋島型配㯰とフリーレイアウト（表 3 ）を比較すると、プライバシーとノイズについては大差はなかっ た（表 $6,8 ）$ が、フリーレイアウトはセクション間のコミュニケー ションにおいてより優れていると言えよう（表 10）。

大部屋島型における座席位置について、末端部座席は座席列の中 央部や頭端部よりも多くの視覚的・聴覚的プライバシーを得ること が出来る（表 $6,8 ）$ 。情報の入手については逆の傾向を示し、末端 部座席は中央部や頭端部に比して、自身のセクションからも他のセ クションからも僅かな情報しか得られていない（表 10）。

座席の囲み方（表 4,5）はプライバシーやコミュニケーションに 最も強い媒介的な影響を与えるようであり、囲みの数と高さが增す につれ知覚された視覚的プライバシーも增し (表 6 )、ノイズによる 阻害も減じるが（表 8)、しかし、充分な情報を得ることも出来にく くなっている(表 10)。これは、配置や囲みの程度とは関わりなく、 大多数の就業者が個人的に情報交換を行っているという、日本の就 業環境における特徽に依るものと考えられる（表 12）。

物理的な特性に関わらず、約半数の就業者は彼等のワークプレー スを喧しいと思っており、その約 1/3 は仕事に集中しにくいとして いる。最低の囲みしかない就業者の $1 / 3$ は、より多くの・高い囲み を求めている(表 5 )。すべての就業者の半数は、上司に見られるこ とは不必要なことであると感じ、彼等の半数は不快を訴えている。 人に一人はそのワークプレースを変えたいと望んでおり、ノイズと ブライバシーに関する苦情が最大の理由となっている（表 13）。よ り良い就業環境を望む彼等の殆どは、より適切な、より機能的なレ イアウトへの変更を述べている（表 14）。

相関性に関する分析によれば、コミュニケーションのし易さが生 産性に最も関係し、また、ある程度の視覚的プライバシーの確保は、 生産性に関する殆ど全ての指標に関連している。しかしながら、ノ イズは生産性とは殆ど関係せず、就業者の完成し得る仕事量とは逆 相関している（表 15）。

フリーレイアウトと大部屋島型配置とを比べると、後者も又効率 的であり得るが、囲みのあり方の注意深いデザインが重要である。 生産的なワークブレースにとって、有る程度の水淮の囲みは提供さ れるべきであるが、過度の囲みは生産性とフェイスッーフェイスの コミュニケーション（今もなお、日本の組織における情報獲得の主 要方法) とを阻害する。 